\title{
RELASI GENDER DALAM KELUARGA PASANGAN PERNIKAHAN DIFABEL DI KUDUS JAWA TENGAH
}

\author{
Zaimatus Sa'diyah \\ Jurusan Tarbiyah STAIN Kudus \\ zaimah.afnan@gmail.com
}

\section{ABSTRAK}

Motif yang melandasi keputusan sebuah perkawinan serta pola relasi antara pasangan memegang perang penting dalam menjaga ketahanan sebuah bangunan pernikahan, termasuk di dalamnya pernikahan pasangan difabel. Tulisan ini mencoba untuk menelusuri motif yang mendasari pernikahan pasangan difabel di Kudus, serta pola relasi dalam pernikahan mereka. Penelitian kualitatif ini menunjukkan bahwa: 1 . Motif yang melatarbelakangi pernikahan sesama difabel adalah kesamaan "status" difabel yang ada pada mereka. 2. Relasi dalam rumah tangga pasangan difabel terjalin dengan baik. Kerjasama dan komunikasi yang terbangun menjadikan pembagian tugas domestic dan public dilakukan dengan fleksibel. Sementara pada pasangan difabel-non difabel data yang ditemukan adalah: 1.Motif utama pernikahan adalah untuk mendapatkan kondisi kehidupan yang lebih baik. 2. Relasi yang baik terbangun antara pasangan difabel laki-laki yang menikah dengan perempuan non difabel. Sementara pasangan difabel perempuan yang menikah dengan laki-laki non difabel, relasi rumah tangga tidak terjalin dengan baik sehingga menyebabkan kandasnya bangunan rumah tangga. 
Kata Kunci: Pernikahan, motif, relasi pasangan, penyandang disabilitas

\section{ABSTRACT}

The motif behind any marriage and relationship built between couples take a big part in its sustainability. This paper is going to describe the motif and relationship between disabled couples in Kudus. All the informants in this research are people with disability which bounded in marital contract. Through qualitative design, this research finds that: 1 . The motif behind marriage between disabled couples is the sameness of disability they anguish. 2. The relationship between disabled couples built on a good cooperation and communication. On the other hand, the data found in mixed marriage (between disabled person and normal person) shows that: 1. The motif behind this marriage is to get the better life where disabled person marry normal person. 2. Good relationship found in disabled man-normal woman marriage while bad relationship found in disabled woman-normal man marriage which leads to divorce.

Keywords: the marriage, the motif, relationship between couples, disabled person

\section{A. Pendahuluan}

Keragaman dalam kehidupan merupakan sunnatullah yang memberi warna dan tidak bisa dihindari dalam kehidupan manusia. Keragaman dimaksud tidak hanya dalam perbedaan suku, ras, budaya, agama, jenis kelamin maupun peran yang dilakukan oleh masing-masing individu namun juga keragaman bentuk penciptaan Allah pada manusia. Artinya ada manusia yang tercipta dalam bentuk sempurna dalam arti yang sesungguhnya, namun ada juga yang tercipta denganketidakmampuan tertentu (disabilitas).Kondisi disabilitas yang dialami oleh sebagian individu sudah seharusnya tidak menjadi alasan masyarakat untuk memandang sebelah mata dan memberikan penilaian negative, Mastyarakat diharapkanmampu 
menyadarinya sebagai keragaman yang natural, sehingga sikap yang muncul dalam interaksi sosial dengan para penyandang kekurangan fisik ini juga akan natural selayaknya interaksi dengan individu pada umumnya.

Tidak dapat dipungkiri bahwa kondisi sosial masyarakat secara umum sangat berperan dalam pembentukan pola pikir masyarakat itu sendiri. Artinya, ada nilai-nilai dan norma-norma yang secara turun-temurun baik disadari maupun tidak telah membentuk pemahaman masyarakat terhadap sesuatu. Pemahaman ini kemudian dapat terlihat dalam simbol yang diberikan pada sesuatu dengan asosiasi yang melekat pada dirinya (Lubis, 2015: 54). Dalam konteks kekurangan fisik misalnya, pemilihan kata "cacat" menunjukkan pemahaman masyarakat dan konsep yang terbentuk dalam diri mereka tentang kata "cacat" ini. Disadari atau tidak, pemilihan kata ini berpengaruh terhadap sikap yang muncul dalam interaksi dengan para penyandang "cacat" ini, baik dalam bentuk sikap kasihan, iba, proteksi berlebihan atau bahkan penghinaan. (Purwanta, 2012: 258)

Upaya untuk merubah mindset masyarakat adalah pembaharuan sebutan dengan filosofi yang mendalam. Kata cacat yang dalam bahasa inggris diartikan sebagai disabledicoba untuk diformulasikan menjadi kata baru yang lebih ramah dan memberikan kesan positif. Formulasi yang kemudia ditawarkan adalah kata difabel yang merupakan akronim dari diffable (Different Ability People) yang mempunyai arti "orang yang memiliki kemampuan berbeda”.Tentu ada harapan positif yang terselip dalam penggunaan kata yang kontra mainstream ini. Harapan agar dengan istilah difabel ini masyarakat secara sadar akan berfikir bahwa mereka yang selama ini dianggap cacat sebenarnya memiliki keterampilan, kemampuan dan keahlian dalam bentuk yang berbeda(Purwanta, 2012: 274).

Sebagai bagian dari masyarakat secara umum, para difabel juga berhak untuk bisa menikmati hidup secara normal selayaknya masyarakat. Pemenuhan kebutuhan dasar seperti sandang, pangan, papan serta pendidikan juga dilindungi oleh undang-undang. Artinya 
tidak ada yang membedakan antara para difabel dan masyarakat non difabel kecuali kekurangan fisik semata.Oleh karena itu Negara telah meratifikasi undang-undang international tentang perlindungan difabel (Convention on the Rights of Person with Disabilities/CRPD) dalam Undang-Undang nomer 19 tahun 2011.

Dalam Undang-Undang nomer 19 tahun 2011 ini Negara memberikan perlindungan hukum terhadap masyarakat difabel khususnya dalam hal kebebasan mobilitas, berekspresi, mendapatkan akses terhadap informasi serta privasi dan banyak lagi permasalahan-permasalahan difabel yang sudah mendapatkan payung hukum. Meski demikian, keberadaan Undang-Undang ini tidak serta-merta menjadikan berbagai permasalahan yang dihadapi para difabel selesai. Terbukti masih banyak terjadi pelanggaran atas hak-hak difabel, beberapa hambatan masih sering ditemui oleh para difabel baik berupa hambatan sarana prasarana fisik dan mobilitas, hambatan prilaku, hambatan hukum dan prosedurnya, hambatan teknologi informasi dan komunikasi serta berbagai bentuk hambatanhambatan lainnya yang menjadikan para difabel belum sepenuhnya bisa sejajar dengan masyarakat pada umumnya (Kurniawan, 2015: viii).

Berbicara tentang hukum tentu berbeda dengan ranah psikososial. Artinya, para difabel memang telah mempunyai payung hukum terkait dengan perlindungan Hak Asasi Manusia. Terlepas dari sejauh mana pemerintah telah melaksanakan kewajibannya untuk menjalankan amanat yang tertuang dalam undang-undang tersebut, ada banyak ruang-ruang kehidupan para difabel yang sangat menarik untuk diteliti terutama terkait dengan ranah psikososial. Salah satu ranah psikososial yang dimaksud dalam tulisan ini adalah yang terkait dengan pernikahan bagi para difabel, khususnya mereka yang berdomisili di kabupaten Kudus.

Berdasarkan pengamatan yang dilakukan oleh penulis, banyak diantara para difabel yang memutuskan untuk membujang atau tidak menikah hingga usia senja, meski tidak sedikit pula pasangan 
difabel yang membina rumah tangga dalam keterbatasan fisik. Meski bukan satu-satunya alasan, Hurlock menyatakan bahwa cacat fisik mempunyai peran cukup besar mendorong manusia dewasa untuk tidak menikah selain alasan karir, keengganan untuk memikul tanggungjawab serta gaya hidup dan kelainan orientasi seksual (Hurlock, TT: 300).

Bagi laki-laki ataupun perempuan dewasa keputusan untuk tidak menikah memunculkan resiko, namun resiko ini lebih bisa diminimalisir pada laki-laki. Artinya, laki-laki dewasa yang memutuskan untuk tidak menikah cenderung lebih mudah untuk menyesuaikan diri dengan lingkungan dan resiko yang diterimanya. Kondisi masyarakat juga lebih bisa memaklumi jika keputusan untuk membujang ini diambil oleh laki-laki.Tidak demikian adanya jika keputusan itu diambil oleh seorang perempuan, pandangan miring masyarakat terhadap perempuan yang tidak menikah masih sangat tajam. Label sebagai perawan tua atau tidak laku dan stigma negatif lainnya seakan menghapus segala potensi positif yang dimiliki oleh para perempuan yang memilh untuk membujang ini. Pandangan dan stigma negatif ini akan semakin berat membebani perempuan difabel karena beban psikososial yang ditanggung berlipat ganda, selain sebagai perempuan yang tidak menikah juga sebagai difabel (Dayaki, 2013: 15).

Beberapa penelitian menunjukkan bahwa jumlah perempuan difabel yang memutuskan untuk membujang lebih tinggi dibanding jumlah laki-laki difabel (Fiduccia, 1999: 4). Hal ini tentu tidak terlepas dari kultur yang terbangun di tengah masyarakat yang menjadikan perempuan sebagai bagian masyarakat yang lemah. Kultur yang mengakar di tengah masyrakat ini menanamkan keyakinan bagi para perempuan difabel untuk tidak menambah beban permasalahan hidup dengan menikah.Artinya keputusan untuk tidak menikah merupakan keputusan yang tepat agar tidak ada lagi permasalahan-permasalahan yang muncul pasca pernikahan. Karena tanpa menikah saja sudah banyak permasalahan yang harus 
mereka hadapi baik sebagai perempuan ataupun sebagai difabel. Tidak dapat dipungkiri bahwa konsep dan pola pikir seseorang juga terbentuk oleh lingkungan.Pandangan seseorang atas baik buruknya sesuatu yang menjadi landasan dalam pengambilan keputusan serta penentuan sikapnya banyak dipengaruhi oleh konsep umum yang terbangun dalam sebuah masyarakat (Badawy, 2000: 8).

Meski demikian, tidak sedikit pula pasangan difabel yang berhasil membangun rumah tangga idaman.Kekurangan fisik yang mereka miliki tidak menjadi penghalang untuk bisa hidup mandiri memenuhi kebutuhan rumah tangga, baik kebutuhan fisik maupun psikis. Tulisan ini mencoba untuk membahas tentang pernikahan para difabel yang tinggal di kabupaten Kudus khususnya yang terkait dengan latar belakang pengambilan keputusan untuk menikah serta pola relasi pasangan dalam rumah tangga.

\section{B. Pembahasan}

\section{Konsep Pernikahan dalam Islam}

Pada hakikatnya tidak ada yang berbeda antara para difabel dengan non difabel dalam hal naluri untuk memenuhi kebutuhan psikososial berumah tangga. kondisi disabilitas yang mereka alami tidak serta merta menghapus kecenderungan alamiah untuk menyukai lawan jenis dan membina bahtera rumah tangga. Hanya saja, tidak semua orang berkesempatan untuk mewujudkan keinginan untuk menjalin hubungan sakral dalam ikatan perkawinan dan membina biduk rumah tangga.

Islam sebagai sebuah manhaj atauway of life secara gamblang menyuratkan kebutuhan untuk saling melengkapi dalam ranah psikosial dalam bentuk rumah tangga sebagaimana yang tertuang dalam beberapa ayat Al-Quran. Bahkan Rasulullah SAW menganjurkan para sahabatnya untuk menikah karena menikah juga merupakan salah satu bentuk ibadah. Di sini terlihat bahwa Islam memberikan ruang sangat luas dalam memahami makna ibadah. 
Artinya ibadah tidak hanya diartikan sebagai ritual hubungan antara manusia sebagai 'abid dengan Allah sebagai ma'bud.

Dalam sebuah hadis riwayat Bukhari dan Muslim dari Anas diceritakan bahwa telah datang beberapa orang sahabat ahli ibadah ke rumah istri-istri Rasulullah SAW untuk bertanya tentang ibadah Rasulullah SAW. Ketika para istri Rasulullah SAW menceritakan perihal ibadah ysng ditanyakan, mereka menganggap bahwa ibadah Rasulullah SAW sangatlah sedikit (dibanding ibadah yang mereka lakukan), lalu merekapun berkata: dimanakah posisi kami dibandingkan Rasulullah SAW? Padahal Allah telah mengampuni semua dosa beliau yang telah lalu dan yang akan datang? Maka salah satu diantara mereka berkata: "Aku senantiasa shalat sepanjang malam”, lelaki keduapun berkata: “Aku berpuasa sepanjang tahun dan tidak pernah berbuka", lalu lelaki ketiga berkata: "Aku menjauhkan diri dari wanita dan tidak menikah selamanya”. Lalu Rasulullah SAW datang dan berkata: "Kalian yang mengatakan itu semua? Sesungguhnya Aku adalah makhluk Allah yang paling takut kepadaNya dan hambaNya yang paling bertakwa, tapi aku berpuasa dan berbuka, shalat dan tidur serta menikahi wanita, maka barang siapa yang tidak menerima sunnahku bukanlah termasuk golonganku"(Qardhawi, 1996: 215).

Hadis di atas merupakan salah satu contoh dari sekian banyak hadis yang menjelaskan tentang anjuran menikah bagi laki-laki dan perempuan dewasa. Bahkan secara lebih jauh ada nilai-nilai normatif yang menjadi tujuan perkawinan dalam Islam:

1. Memenuhi kebutuhan dasar manusia sebagai makhluk sosial.

Manusia sebagai makhluk sosial tentu tidak bisa memnuhi semua kebutuhan kehidupanya secara mandiri, baik kebutuhan moral maupun material.Salah satu kebutuhan dasar psikologis manusia adalah perasaan untuk mencintai dan dicintai.Perasaan yang hanya bisa terpenuhi dengan keterikatan dua belah pihak secara emosional (Hassan, 1990: 93-128). Mencintai dan dicintai memang tidak hanya menjadi milik pasangan yang menikah, 
artinya setiap makhluk hidup di bumi ini disarankan untuk senantiasa menyebarkan rasa cinta dan kasih sayang terhadap sesama agar tercipta kehidupan yang penuh kedamaian.Namun ada kebutuhan yang lebih dari sekedar cinta universal, yaitu cinta yang bisa menjadi jalan untuk menyempurnakan kebahagiaan dua orang dalam wujud pernikahan.

Memang pernikahan tidak hanya terkait dengan cinta dan pemenuhan kebutuhan biologis manusia dewasa, namun pernikahan menjadikan cinta dan pemenuhan kebutuhan biologis ini terjaga dalam bingkai sakral yang membedakan manusia sebagai makhluk mulia dengan selainnya.Artinya, cinta dan pemenuhan kebutuhan biologis bisa saja dipenuhi oleh manusia dewasa tanpa pernikahan, namun hal ini tentu menjadikan derajat dan kemuliaan manusia menurun.Di sinilah kemudian Islam mensyariatkan pernikahan dan melarang perzinahan.

Dalam memenuhi kebutuhan akan pernikahan ini, Islam tidak menjadikan kesehatan dan kesempurnaan fisik sebagai prasyarat keabsahan sebuah pernikahan. Anjuran untuk menikah dalam Islam berlaku universal tanpa membedakan kesempurnaan fisik dan kekurangannya.Selama kedua belah pihak sepakat untuk menjalin ikatan pernikahan untuk menciptakan keluarga bahagia dengan memenuhi rukun dan syarat yang telah ditetapkan dalam Islam, maka segala perbedaan termasuk di dalamnya perbedaan ras, warna kulit, suku bangsa dan juga bentuk fisik tidak lagi menjadi penghalang keabsahan pernikahan. Dengan demikian masyarakat difabel juga mendapat perlindungan hukum dalam pemenuhan kebutuhan dasar untuk menikah.

Rasa cinta yang melahirkan penerimaan atau ridla dari kedua belah pihak menjadi kunci utama kebahagiaan dalam sebuah pernikahan.Oleh Karena itu, sebelum melangsungkan pernikahan kedua calon mempelai diperbolehkan untuk saling melihat dan mengenal termasuk mengetahui kekurangan fisik masing-masing. Dalam sebuah hadits yang diriwayatkan Imam 
Ahmad dan Thabrany disebutkan bahwa Rasulullah SAW memerintahkan Mughirah bin Syu'bah yang hendak menikahi seorang perempuan untuk melihat perempuat tersebut, karena mata adalah jendela hati, jika mata bisa menerima segala kelebihan dan kekurangan fisik calon pasangannya maka hati juga akan lebih mudah untuk menerimanya (Qardhawi, 1996: 221). Pada dasarnya, kekurangan fisik pada difabel bukanlah penghalang untuk menjalin hubungan dalam bahtera rumah tangga. Selama kondisi ini bisa diterima oleh kedua belah pihak sejak awal menikah, sehingga tidak menjadi akar permasalahan dalam mengarungi bahtera rumah tangga (Chaim, 2007: 53).

2. Regenerasi dan Investasi

Sadar ataupun tidak manusia mempunyai keinginan untuk mendapatkan penghargaan atas eksistensinya baik dalam lingkungan terbatas maupun dalam ranah yang lebih luas. Eksistensinya akan semakin terlihat manakala seseorang mempunyai keturunan dari pernikahannya.Meskipun pernikahan tidak selalu menjanjikan keberadaan keturunan, namun pernikahanlah stu-satunya jalan legal untuk memperoleh keturunan biologis dari pasangan suami istri.Selain itu, perubahan pemahaman masyarakat modern telah menanamkan kesadaran bahwa mempunyai keturunan atau tidak merupakan sebuah pilihan bagi pasangan yang sudah menikah.Maka bisa jadi ada pasangan yang sepakat untuk tidak mempunyai anak karena berbagai pertimbangan seperti karir, kesehatan, ekonomi atau bahkan pertimbangan estetika dan kosmetika.Namun tidak dapat dipungkiri bahwa keberlanjutan eksistensi manusia di bumi bergantung pada pernikahan dan lahirnya keturunan (AlGhazali dalam Al-Mahally, 1995:10).

Selain itu, keberadaan keturunan juga merupakan investasi yang sangat berharga baik untuk kepentingan kehidupan dunia maupun akhirat. Tidak bisa dipungkiri bahwa setiap manusia pasti akan mengalami masa lemah baik karena usia lanjut 
ataupun karena kesehatan. Pada saat itu terjadi, manusia akan sangat bergantung pada bantuan orang lain. Di sinilah peran dari keturunan bisa dirasakan oleh pasangan suami istri.Sebagai salah satu bentuk investasi maka baik dan buruknya keturunan dalam sebuah bangunan rumah tangga sangat bergantung pada baik dan buruknya perlakuan dan pendidikan yang diberikan. Jika anak-anak dibesarkan dalam suasana nyaman, penuh kasih sayang dan mendapatkan pendidikan yang memadai, maka dapat dipastikan bahwa mereka akan memperlakukan kedua orang tua dengan penuh kasih sayang pula. Di sini, Islam berbicara mengenai kualitas sebuah generasi bukan kuantitasnya. Artinya banyak sedikitnya jumlah ketutunan tidak akan membawa manfaat dan kebaikan jika mereka tidak dipersiapkan dengan matang (Madjid, 2000: 118).

Oleh karena itu, Islam sangat memperhatikan pemenuhan hak-hak dan kebutuhan anak-anak dalam sebuah keluarga, khususnya dalam hal penanaman akidah serta etika sejak dini. Dua hal yng menjadi komponen dasar risalah Muhammad SAW. Kekuatan akidah menjadi pondasi utama pembentukan jatidiri seorang anak karena akidah ibarat rambu-rambu yang menjadi penunjuk arah keselamatan bagi seseorang.Sementara akhlak merupakan bingkai keindahan yang menjadikan seseorang mampu beradaptasi dan menempatkan diri tanpa kehilangan jati dirinya (Azzam, 1986:15).

3. Penyempurnaan agama

Bersumber dari riwayat Thabrany diceritakan dalam suatu kesempatan Rasulullah SAW pernah menyatakan bahwa "Jika seorang laki-laki telah diberi pasangan permpuan yang baik maka sesungguhnya Allah telah menolongnya untuk menyempurnakan separuh agamanya, maka hendaklah dia menjaga separuh yang lain” ()(Madjid, 2000: 118). Mengapa demikian besar nilai sebuah pernikahan sehingga setara dengan sekian banyak ibadah lain yang ada dalam syari'at Islam? Hal ini tidak terlepas dari 
besarnya tanggung jawab yang dipikul oleh pasangan suami istri pasca pernikahan.

Suami bertangggung jawab penuh terhadap keselamatan lahir batin istri dan anak-anaknya.Pemenuhan kebutuhan moral dan material menjadi tanggung jawab yang harus diprioritaskan oleh pemimpin rumah tangga ini. Di sisi lain, seorang istri mempunyai tanggung jawab yang tidak kalah berat. Bersama suami dia harus mampu menjadikan rumah tangganya sebagai tempat yang aman dan nyaman bagi semua anggota keluarga. Serbagai sosok terdekat dengan anak-anak yang terlahir, menjadikan istri central figure. Ibu juga memiliki posisi sebagai madrasah pertama (ula madrasah) bersama suami dalam penanaman nilai-nilai positif bahkan sejak anak-anak masih dalam kandungan. Demikian besar tanggung jawab yang harus dipikul oleh suami istri pasca pernikahan, maka tidak heran jika kemudian Rasulullah menyatakan bahwa pernikahan setara dengan separuh tanggung jawab agama.

Satu hal perlu digarisbawahi bahwa suami-istri adalah pasangan yang saling melengkapi. Penggunaan kata zauj dalamQ. Ar-Rum: 21 menunjukkan bahwa suami istri adalah pasangan yang mempunyai kedudukan setara (Hassan, 1990: 93-128), saling melengkapi dan membantu untuk mewujudkan tujuan utama pernikahan yaitu tercapainya sakinahatau ketenangan yang merupakan unsur psikologis utama dalam menciptakan suasana keluarga yang harmonis (Al-Badawy, 1980: 7). Dari keluarga yang harmonis ini akan terlahir generasi bangsa yang memiliki jati diri yang kokoh dan akhlak yang mulia. Tidak dapat dipungkiri bahwa hubungan baik yang terbangun dalam keluarga berpengaruh terhadap pembentukan kepribadian seseorang. (Elizabeth, TT: 300)

4. Penghormatan terhadap perempuan

Pernikahan merupakan ikatan sakral yang mendapat perhatian serius dalam Islam, hal ini terkait dengan salah satu 
fungsi dari pernikahan adalah untuk melegalkan pemenuhan kebutuhan biologi manusai dewasa.Memang, pernikahan tidak selalu berhubungan dengan pemenuhan kebutuhan biologis, namun pernikahanlah satu-satunya jalan yang melegalkan hubungan ini.

Sebelum datangnya Islam, status perempuan tidak berbeda jauh dengan harta milik seseorang yang bisa diperjualbelikan, diwariskan dan juga dipinjamkan atau dihibahkan untuk memenuhi kebutuhan biologis laki-laki.Islam kemudian datang membawa kabar baik dengan mengangkat derajat perempuan sehingga perempuan tidak lagi diposisikan inferior (Barlas, 2002: 170).

Tidak sedikit orang yang menganggap bahwa pernikahan adalah bentuk kesengsaraan yang menjadikan lelaki dan perempuan terikat dan kehilangan kebebasannya (Mutahhari, 1981: 122). Padahal, sejatinya justru pernikahan merupakan bentuk penghormatan terhadap manusia, terutama perempuan. Dengan pernikahan, kesucian serta harga diri perempuan menjadi terjaga disamping kepastian nasab juga terjamin. Mengapa perempuan? Karena dalam pemenuhan hubungan biologis manusia dewasa, wanita yang akan menanggung akibat fisik dan psikis dari hubungan biologis ini, terutama jika terjadi kehamilan. Kehamilan tentu mempengaruhi kondisi fisik dan psikis seorang wanita.Meski sebagian besar wanita merasakan masa kehamilan sebagai pengalaman yang menyenangkan, namun tidak demikian jika kehamilan ini harus dihadapi sendiri oleh seorang wanita tanpa pendamping atau bahkan tanpa kejelasan status ayah biologis dari janin yang dikandungnya. Disinilah letak penghargaan Islam terhadap perempuan melalui lembaga perkawinan. 


\section{Islam dan Penghargaan Terhadap Hak-hak Suami Istri}

Pernikahan sebagai sebuah lembaga yang menyatukan dua manusia dewasa tentu harus dipersiapkan dengan sangat matang oleh kedua belah pihak.Sikap mendahulukan pasangan dan menghargai perbedaan menjadi kunci keberhasilan dalam sebuah bangunan rumah tangga.Satu hal penting yang harus dikedepankan dalam relasi suami istri dalam bangunan pernikahan adalah konsep mu'asyarah bil ma'ruf; kewajiban untuk memperlakukan pasangan dengan sebaik mungkin.Konsep ini tidak hanya wajib dilakukan oleh suami atau istri saja, namun harus diimplementasikan oleh kedua belah pihak.

Konsep mu'asyarah bil ma'ruf tidak hanya berlaku untuk urusan domestik atau internal rumah tangga, namun juga berlaku untuk urusan eksternal.Tentu saja bangunan komunikasi yang terjalin dengan baik menjadi kunci utama keberhasilan konsep ini. (Bastaman, 2005: 202). Rasulullah SAW adalah contoh sempurna bagaimana membangun relasi ideal dalam rumah tangga.Kesediaan Rasulullah SAW untuk membantu setiap pekerjaan istri-istri beliau dalam memenuhi kebutuhan sehari-hari adalah contoh nyata bahwa urusan internal atau domestik rumah tangga bukanlah tanggung jawab mutlak seorang istri.Demikian juga sebaliknya, pengorbanan Khadijah ummul mu'minin untuk membantu perjuangan Rasulullah SAW dalam berdakwah merupakan contoh nyata emansipasi wanita di luar rumah.

\section{Potret Pernikahan Pasangan Difabel Kudus}

Seluruh difabel yang menjadi informan dalam tulisan ini adalah muslim, oleh karena itu landasan teoritis yang menjadi pijakan dalam tulisan ini tidak lepas dari kerangka konseptual keislaman. Sebagaimana dijelaskan pada pembahasan sebelumnya, bahwa Islam menganjurkan pernikahan bagi laki-laki dan perempuan dewasa.Anjuran untuk menikah ini berlaku universal tanpa melihat perbedaan ras, suku bangsa, warna kulit, serta kesehatan dan kesempurnaan fisik seseorang.Dengan demikian, anjuran untuk 
menikah juga berlaku bagi para difabel dewasa. Hal ini juga yang mendasari pernikahan beberapa pasangan difabel muslim di Kudus. Dari tujuh pasangan difabel yang berhasil ditemui oleh penulis, tiga pasangan diantaranya adalah pasangan difabel, sementara empat pasang lainnya adalah pasangan difabel dan non difabel.

\section{a. Pernikahan antara sesama difabel}

Ada beberapa hal menarik yang bisa dituliskan terkait pernikahan pasangan difabel di Kudus. Yang pertama adalah terkait alasan memilih pasangan sesama difabel. Pada umumnya pasanganpasangan ini mengalami kekurangan fisik yang sama, baik netra, rungu maupun daksa. Hal ini tentu tidak terlepas dari komunitas tempat mereka bersosialisasi terutama dalam bentuk organisasi yang menjadi wadah berkespresi, berpendapat, berbagi serta berlatih keterampilan tertentu.Pasangan netra -sebut saja Hebat dan Bungaini misalnya mengaku pernikahan mereka bermula dari perkenalan saat mereka sama-sama mengikuti pelatihan keterampilan memijat yang diadakan oleh Dinas Sosial Kudus. Pelatihan yang diadakan dalam waktu sekitar satu tahun lebih ini mampu menumbuhkan benih cinta pada pasangan Hebat dan Bunga.

Hebat dan Bunga mengaku berkenalan sendiri tanpa bantuan perantara, kebersamaan yang terjalin serta pertemuan yang intens menjadikan cinta yang terjalin diantara keduanya semakin kuat hingga kemudian mereka memutuskan untuk menikah.Keluarga besar dari pasangan Hebat dan Bunga mendukung pernikahan ini, dukungan diberikan karena persamaan kondisi fisik keduanya sebagai difabel netra. Meski kekhawatiran akan kemadirian pasangan ini sempat muncul dalam benak keluarga, namun pasangan Hebat dan Bunga mampu menunjukkan pada keluarga dan masyarakat bahwa mereka mampu mandiri dalam keterbatasan. Bangunan cinta kasih yang terbangun antarHebat dan Bunga tetap terjaga hingga saat ini, mereka dikaruniai dua orang anak yang sehat-sehat.Keberadaan anak-anak ini cukup banyak membantu Hebat dan Bunga karena anak-anak merekalah yang menjadi mata dan penunjuk jalan bagi 
Hebat dan Bunga saat harus berada di ruang publik.

Berbeda dengan Hebat dan Bunga yang berhasil menjalin cinta kasih dalam bangunan rumah tangga tanpa melalui perantara, Pasangan Kuat dan Harum; sesama tuna daksa yang mengalami kendala fisik di kaki, menikah karena perjodohan. Kuat adalah seorang laki-laki cerdas yang terlahir dari pasangan--- saat dilahirkan Kuat adalah bayi sehat dan normal, namun pada saat usia 8 tahun (kelas dua SD) dia terjatuh di sungai, trauma kaki yang dialaminya ternyata menyebabkan salah satu kakinya mengecil. Kondisi fisik ini tidak menyurutkan tekadnya untuk terus maju. Dengan dukungan keluarga, Kuat terus bersemangat melanjutkan pendidikan hingga kemudian dia mengikuti pelatihan keterampilan elektronika yang diadakan oleh Dinas Sosial. Keterampilan yang diperolehnya menjadikan Kuat mampu mandiri secara ekonomi. Pada saat inilah kemudian keluarganya memperkenalkan pada Harum, gadis cantik yang juga mengalami kekurangan fisik di kaki akibat kecelakaan. Pertemuan ini mampu melahirkan benih cinta diantara keduanya hingga keputusan untuk menikahpun diambil. Sekali lagi bahwa sikap keluarga di sini sangat mendukung terutama dari pihak keluarga Harum.Salah satu alasan dukungan ini adalah karena Kuat dan Harum sama-sama difabel daksa. Bagi keluarga Harum kekhawatiran akan kehidupan pasca pernikahan dapat diminimalisir karena kondisi fisik Kuat tidak jauh berbeda dengan Harum. Maka prasangka-prasangka negatif dalam rumah tangga akibat kondisi fisik Harum bisa diminimalisir dan bahkan tidak lagi terlintas dalam benak keluarga besar Harum.Hingga saat ini Kuat dan Harum mengaku sangat bahagia dengan rumah tangga yang dibinanya. Apalagi saat ini Harum sedang mengandung anak pertama buah cinta kasihnya dengan Kuat; suami yang sangat dia cintai.

Selain komunitas, faktor kedua yang mendorong pasangan sesama difabel untuk menikah dengan sesama difabel adalah empati dan simpati yang memunculkan perasaan nyaman dan percaya. Dalam kaca mata psikologis, emosi atau perasaan setiap manusia 
berpusat pada dua dasar: perasaan yang menyakitkan atau perasaan yang menentramkan. Perasaan yang menyakitkan mendorong seseorang untuk menghindari sesuatu, sebaliknya perasaan yang menentramkan mendorong pada pencapaian target(Daradjat, 1982: 28). Perasaan nyaman ini timbul karena kesamaan yang menyatukan para difabel ini. Maka tidak heran jika kemudian perasaan nyaman yang muncul mendorong pasangan sesama difabel ini untuk mencapai target, dalam hal ini menjalin cinta kasih dalam bingkai rumah tangga.Sejatinya pembentukan emosi seseorang bukanlah sesuatu yang instan, rentang pertumbuhan sejak masa prenatal hingga dewasa berperan besar dalam pembentukan emosi dan karakter seorang. Ada dua faktor penting yang mempengaruhi pembentukan karakter seseorang sepanjang rentang pertumbuhannya; nature dan nurture.Nature merupakan sifat bawaan yang dimikili seseorang sejak lahir, sementara nurture adalah faktor-faktor eksternal seperti lingkungan, pola pengasuhan dan pendidikanyang mempengaruhi pembentukan karakter seseorang (Desmita, 2013: 32, Madzahiry, 1997: 12, Talu', 1995: 9).

Dalam konteks para difabel, nature dan nurture tentu mempunyai peran yang sangat besar dalam pembentukan karakter mereka.Pola asuh dalam keluarga serta komunitas sesama difabel secara otomatis memupuk tumbuhnya karakter penuh empati pada sesama difabel sehingga kebersamaan dengan komunitas difabel melahirkan perasaan nyaman dan juga kepercayaan (trust). Relasi yang baik yang terbangun antar sesama difabel membantu para difabel untuk bisa melebur dan bersosialisasi sehingga menumbuhkan kesehatan mental dan karakter yang positif pada para difabel. Berdasarkan hal inilah kemudian pasangan difabel merasa menemukan kecocokan dan kesamaan status sehingga kemudian mereka memutuskan untuk menikah.

Dalam pola relasi rumah tangga, pasangan difabel kudus yang menjadi informan dalam tulisan ini menyatakan bahwa kerjasama dan saling membantu menjadi kata kunci dalam membangun 
suasana yang penuh harmoni. Pasangan Hebat dan Bunga misalnya, bekerja sama membuka layanan pijat bagi masyarakat demi memenuhi kebutuhan keluarga. Demikian juga dengan pasangan Lanang dan Mawar yang merupakan pasangan difabel netra. Dengan keterampilan pijat yang dimiliki oleh keduanya, layanan pijat pada masyarakat bisa diberikan dengan tetap menjaga normnorma agama.Hebat melayani pemijatan bagi pelanggan laki-laki, sementara Bunga melayani pemijatan bagi pelanggan perempuan, hingga keduanya merasa nyaman dengan pembagian tugas ini. Sementara untuk urusan domestik rumah tangga, keduanya saling membantu, urusan dapur tidak melulu dikerjakan oleh Bunga atau Mawar. Dengan kesadarannya, Hebat dan juga Lanang membantu sang istri untuk menyelesaikan pekerjaan rumah tangga.

Demikian juga dengan pasangan Kuat dan Harum, dengan keterampilan yang dimilikinya, Kuat membuka usaha servis elektronik di rumahnya untuk memenuhi kebutuhan ekonomi rumah tangganya.Sementara Harum tidak kalah cekat membantu memenuhi kebutuhan rumah tangga, tidak hanya kebutuhan domestik yang dia penuhi namun juga membantu Kuat untuk mobilisasi, karena Harum mampu mengoprasikan kendaraan roda dua, sehingga untuk keperluan mobilisasi Kuat bergantung penuh pada Harum istrinya.

Dalam pembagian tugas pengasuhan anak, para pasangan difabel yang telah memiliki anak bekerja sama dalam melaksanakan tugas pengasuhan ini. Masing-masing menerapkan konsep pengasuhan yang fleksibel.Ketika Bunga/Mawar sedang melayani pelanggan pijatnya misalnya, maka dengan kesadarannya Hebat/ Lanang mengambil alih tanggung jawab pengasuhan anaknya yang masih balita. Bahkan ketika harus mengikuti kegiatan kajian di luar rumah misalnya, tanpa rasa malu Hebat/Lanang membawa anaknya ikut serta agar tidak mengganggu Bunga/Mawar dalam melayani pelanggannya. Meski secara umum anak-anak mereka tergolong anak yang penurut namun bagi pasangan Hebat dan Bunga/Lanang dan Mawar kepuasan pelanggan menjadi prioritas utama yang harus 
dijaga, maka jangan sampai muncul kekecewaan dari para pelanggan yang disebabkan oleh gangguan anak-anak mereka sekecil apapun bentuknya.

Menyadari akan pentingnya pendidikan bagi anak-anaknya, pasangan difabel ini berusaha keras untuk bisa menyekolahkan anak-anak mereka agar generasi penerus ini mampu mengecap pendidikan setinggi mungkin. Semangat yang luar biasa menjadikan pasangan difabel ini terus bergandengan tangan mewujudkan citacita mulia mereka.Contoh nyata dalam bentuk ikhtiar untuk terus meningkatkan ilmu pengetahuan mereka berikan dengan terus aktif dalam kegiatan pengajian bagi komunitas difabel yang ada di lingkungan mereka. Para pasangan difabel seringkali membawa serta anak-anak mereka dalam kegiatan komunitas yang ada, selain sebagai bentuk riil contoh akan semangat mengejar mimpi melalui ilmu pengetahuan, hal ini juga dilakukan karena khawatir akan keselamatan anak-anak karena tidak ada orang dewasa yang mendampingi mereka di rumah. Sebagaimana data di lapangan, mayoritas difabel di kudus tidak mendapatkan pendidikan formal yang maksimal. Mahalnya biaya pendidikan di Sekolah Luar Biasa pada saat mereka dalam masa pertumbuhan menjadi alasan keluarga untuk tidak menyekolahkan mereka di SLB. Sehingga kemampuan literasi difabel ini rata-rata diperoleh di usia dewasa, khususnya pada saat mereka mengikuti pelatihan keterampilan memijat yang diadakan oleh Dinas Sosial.

Konflik dalam rumah tangga pasangan difabel tidak berbeda jauh dengan pasangan rumah tangga non difabel.Pasti ada permasalahan-permasalahan yang muncul dalam rumah tangga baik disebabkan oleh factor internal maupun eksternal.Namun pada umumnya mereka mampu menyelesaikan permasalahan dalam rumah tangga dengan baik.Sikap saling memaafkan kesalahan pasangan, serta kesadaran akan pentingnya mengedepankan keselamatan rumah tangga khususnya anak-anak menjadikan berbagai permasalahan yang mereka hadapi bisa diselesaikan dengan baik. 
Konsep mu'asyarah bil ma'rufyang menjadi rubbangunan sebuah rumah tangga dapat diimplementasikan dengan baik, sehingga pasangan difabel ini secara umum menyatakan bahwa pernikahan mereka bahagia.

\section{b. Pernikahan antara difabel dengan pasangan non difabel}

Tidak selamanya difabel menikah dengan sesame difabel.Cinta yang menjadi pintu hubungan manusia dewasa untuk membangun rumah tangga merupakan fitrah atau naluri yang diberikan Allah pada semua manusia tanpa membedakan kondisi fisik seseorang. Tidak ada seorangpun yang bisa memilih pada siapa dia mencinta karena cinta adalah anugrah dari Allah yang sudah ditetapkan pada setiap manusia.(Ibyari, TT: 7). Ada empat pasangan yang menjadi informan dalam tulisan ini, pasangan pertama antara seorang difabel netra sebut saja namanya Gigih dengan seorang gadis non difabel Ayu (nama samaran), pasangan kedua antara seorang difabel netra dengan seorang perempuan non difabel (Untung-Fulanah), pasangan ketiga antara seorang perempuan difabel netra dengan laki-laki non difabel (Yasmin-Fulan), dan informan keempat adalah perempuan difabel rungu (Sutra) yang menjadi korban pelecehan seksual yang dilakukan oleh laki-laki non difabel hingga hamil dan mempunyai anak. Ada beberapa perbedaan mendasar antara pasangan sesama difabel dan pasangan difabel-non difabel dalam hal motif yang mendorong untuk menikah, pola relasi dalam rumah tangga serta ketahanan rumah tangga yang mereka bangun.

Pada difabel perempuan yang menikah dengan laki-laki non difabel, motif untuk menikah adalah untuk mendapatkan pasangan yang lebih baik dalam arti fisik dari dirinya. Ketika ada laki-laki non difabel yang mendekati dan menyatakan rasa cinta serta berniat untuk membangun hubungan rumah tangga ada perasaan bangga yang muncul pada perempuan difabel. Perasaan bangga ini tidak lepas dari kesadaran akan keterbatasan kondisi yang ada pada dirinya.

Pada pasangan Yasmin-Fulan misalnya, Yasmin sebagai PALASTREN, Vol. 9, No. 1, Juni 2016 
perempuan difabel netra menyatakan perasaan bahagia dan bangga saat Fulan mendekati dan menyatakan niatnya untuk mempersunting Yasmin sebagai istri. Perbedaan fisik yang selama ini membuatnya merasa kurang seketika lebur.Baginya kedatangan Fulan merupakan anugrah terindah yang tidak pernah terlintas dalam benaknya. Setelah proses perkenalan keduanya memutuskan untuk menikah. Permasalahan kemudian muncul saat Fulan sebagai kepala rumah tangga tidak bisa melaksanakan kewajibannya dalam memenuhi nafkah keluarga, baik nafkah lahir maupun batin. Padahal Yasmin adalah sosok nan mandiri di balik keterbatasannya. Dengan keterampilan memijat yang dia miliki, tanggung jawab pemenuhan nafkah keluarga berpindah ke punggungnya. Penghasilannya dari memijat sebenarnya lebih dari cukup, namun Fulan sang suami rupanya tidak bertanggung jawab dan hanya memanfaatkan kelemahan fisik Yasmin. Rupiah demi rupiah yang terkumpul dijadikan modal untuk membeli rumah, namun Yasmin tidak pernah tahu bahwa rumah yang ia tempati saat ini tidak tertulis atas nama dirinya, namun atas nama suaminya. Ketidakjujuran dan sikap memeras ini kemudian memunculkan berbagai konflik dalam rumah tangga Yasmin-Fulan hingga akhirnya mereka memutuskan untuk berpisah.Dalam kasus ini Yasmin menjadi korban egoisme Fulan yang memanfaatkan kelemahan Yasmin sebagai perempuan dan difabel netra sekaligus.

Motif yang sama melatarbelakangi kisah cinta antara Sutra; seorang difabel rungu dengan laki-laki non difabel; Gagah. Sebagai seorang difabel rungu kendala yang dihadapi oleh Sutra dalam kehidupan sehari-hari tentu tidak seberat yang dihadapi para difabel netra. Apalagi paras cantik yang dimiliknya menjadikan setiap orang jatuh hati padanya. Kedekatannya dengan Gagah merupakan satu kebanggan tersendiri baginya, apalagi Gagah menyatakan rasa cinta dan berjanji akan menikahinya. Janji-janji manis yang terucap membuat Sutra terlena hingga mereka melakukan hubungan di luar nikah dan mengakibatkan kehamilan. Saat itulah jati diri Gagah 
terlihat nyata, dia bukanlah laki-laki yang bertanggung jawab. Tanpa mempertimbangkan kondisi Sutra dan tanpa rasa bersalah, Gagah pergi meninggalkan Sutra sendiri dan melupakan janji-janji manis akan pernikahan yang pernah disampaikan pada Sutra. Sutra harus menanggung sendiri akibat dari cinta buta yang melenakannya hingga bayi mungil tak berdosa buah cinta terlarang ini lahir ke dunia.

Meski tidak terjadi pernikahan antara Sutra dan Gagah, namun motif yang melatarbelakangi hubungan percintan antara Sutra dan Gagah tidak berbeda dengan motif yang melatarbelakangi kisah cinta antara Yasmin dan Fulan. Sutra dan Yasmin sama-sama memiliki harapan yang besar dari hubungan yang dijalin dengan laki-laki non difabel.Harapan untuk bisa mengangkat status sosial meski ternyata harapan itu tidak terwujud bagi Sutra. Dua potret pernikahan dari perempuan difabel dan laki-laki non difabel ini menggambarkan betapa perempuan difabel masih rentan menjadi korban tindakan laki-laki yang tidak bertanggung jawab.

Berbeda dengan dua pasangan di atas, pasangan Gigih-Ayu dang Untung-Fulanah tetap bisa bertahan hingga saat ini.Pada pasangan Gigih-Ayu, keterbatasan fisik pada Gigih yang merupakan seorang difabel Netra tidak menjadi alasan yang menghalangi pernikahan mereka. Meski pada awalnya keluarga Ayu merasa keberatan dengan keputusan Ayu untuk menikah dengan lelaki difabel netra, namun dengan komunikasi yang baik Ayu mampu meyakinkan keluarganya bahwa dia benar-benar mencintai Gigih dan akan membuktikan bahwa rumah tangga yang dibangunnya akan bahagia. Satu hal yang menjadi daya tarik Gigih di mata Ayu adalah keluasan ilmu agama yang dimiliki serta sikap/akhlak baik yang dimiliki Gigih. Bagi Ayu pernikahan adalah perjuangan dan pengorbanan.Ayu siap berjuang dan berkorban demi kebahagiaan rumah tangga yang dibangunnya bersama Gigih. Semua ini tentu tidak lepas dari sikap nrimo atau ridla yang ada pada diri Ayu.

Meski saat ini mereka belum memperoleh keturunan, namun 
Gigih dalam keterbatasannya tetap melaksanakan tugas utamanya dalam memenuhi kebutuhan ekonomi keluarga.Dengan bantuan Ayu, Gigih tetap bekerja melayani pelanggan di wisma pijat yang didirikannya. Konsep bahwa kebahagiaan rumah tangga menjadi tanggung jawab suami-istri benar-benar difahami oleh Gigih dan Ayu. Dengan penuh kesadaran Ayu juga bekerja untuk membantu sang suami memenuhi kebutuhan ekonomi rumah tangga.

Kisah yang sama terjadi pada pasangan Untung-Fulanah. Pernikahan mereka pada awalnya mendapat tentangan dari keluarga Untung, karena keluarga besar menganggap bahwa Fulanah bukanlah wanita baik. Namun seiring berjalannya waktu, Untung mampu meyakinkan keluarganya bahwa pilihannya untuk menikah dengan Fulanah adalah yang terbaik untuk dirinya. Motif untuk medapatkan kehidupan dan penghidupan yang lebih baik dari pernikahan dengan perempuan non difabel mendasari keputusan besar dalam hidupnya. Untuk memenuhi kebutuhan ekonomi rumah tangga, UntungFulanah bergantung pada usaha kecil berupa warung yang mereka dirikan.Secara umum rumah tangga yang dibangun terlihat bahagia. Keterbatasan fisik pada salah satu pasangan tidak menjadi sumber permasalahan dalam rumah tangga.Sikap menerima atas kekurangan pasangan menjadi kunci utama kebahagiaan dalam rumah tangga. bSikap menerima ini mampu melahirkan kasih sayang tanpa batas yang menjadi modal utama keberhasilan dan kebahagiaan sebuah rumah tangga. (Mahmud, 1999: 4)

\section{SIMPULAN}

Pernikahan pasangan difabel sebenarnya tidak berbeda dengan pernikahan pasangan non difabel.

Dalam konteks difabel Kudus, ada dua kelompok besar pernikahan difabel; pernikahan antara sesame difabel dan pernikahan antara difabel dan non difabel.Pada pasangan sesama difabel, komunitas dan perjodohan menjadi pintu menuju pernikahan.Empati 
dan simpati karena persamaan kondisi fisik mampu memunculkan rasa nyaman dan percaya sehingga pola relasi rumah tangga lebih mudah dikompromikan baik dalam hal pengasuhan anak atau pemenuhan kebutuhan ekonomi keluarga.Secara umum pasangan difabel ini mampu mewujudkan kebahagiaan dalam rumah tangga yang dibangun.

Sementara itu pada pernikahan antara difabel dan non difabel, motif utama pernikahan adalah untuk mendapatkan kondisi kehidupan yang lebih baik. Ketahanan dan kebahagiaan bangunan rumah tangga dapat terwujud pada pasangan difabel laki-laki yang menikah dengan perempuan non difabel.Sementara pasangan difabel perempuan yang menikah dengan laki-laki non difabel mengalami kegagalan dalam rumah tangga.Di sini dapat ditarik satu kesimpulan bahwa perempuan difabel dalam relasi rumah tangga pasangan difabel-non difabel masih rentan menjadi korban.Kelemahan yang ada para perempuan difabel justru dijadikan senjata oleh sebagian masyarakat untuk melecehkan.

Dari potret pernikahan difabel di atas, masih ada banyak pekerjaan rumah yang harus dilakukan oleh berbagai pihak termasuk pemerintah, lembaga swadaya masyarakat, institusi pendidikan dan juga pemuka agama. Satu tugas besar yang paling utama adalah bagaimana semua lapisan masyarakat ini dengan kesadaran penuh melakukan perubahan pola piker dan sudut pandang terhadap difabel, dari pola pikir yang cenderung merendahkan menuju pola pikir menghargai dan menghormati. Dengan demikian, para difabel tidak lagi dipandang sebelah mata dan mampu mencapai kebahagiaannya termasuk dalam berumah tangga khususnya pada difabel perempuan, karena ternyata dalam bangunan rumah tanggapun mereka masih rentan menjadi korban. 


\section{DAFTAR PUSTAKA}

Al-Mahally, Husain bin Muhammad.(t.t). al-Ifsah' an Aqd al-Nikah 'ala Madzahib al-Arbba'ah. Aleppo: Dar el-Qalam el-Araby

Azzam, Mahfudz Ali.(t.t). Al-Akhlaq fi al-Islam bayna alnadhariyyah. الأخلاق فى الإسلام بين. Kairo: Dar Al-Hidayah

Badawy, As-Sayyid Muhammad. (2000). Al-Akhlaq bayna alFalsafah wa Ilm al-Mujtama'. Qanat Sweis: Dar Al-Ma'rifah Al-Jami'iyyah.

Barlas, Asma. (2002) Believing Women in Islam. Austin: University of Texas Press.

Chaim, Vardit Rispler. (2007) Disbility in Islamic Law. Netherland: Springer.

Daradjat, Zakiah. (1982) Perawatan Jiwa Untuk Anak-Anak. Jakarta: Penerbit Bulan Bintang.

Davaki, Konstantina dkk. (2013). Discriminatioan Generatedby The Intersection of Gender and Disability. European Parliament: Directoral General for International Policies. . Available on http://www.europarl.europa.eu/studies.

Desmita. (2013). Psikologi Perkembangan. Bandung: Remaja Rosdakarya.

Fiduccia, Barbara Waxman dan Leslie R. Wolfe. (1999) Women and Girl with Disabilities: Defining The Issues. Center for Woman Policy Studies and Women \& Philanthropy

Hassan, Riffat. (1990) “An Islamic Perspective." Dalam Becker

J. Women Religion and Sexuality, Studies in the Impact of Religious Teachings on Women. Geneva: WLC Publications

Hurlock, Elizabeth B. (TT). Psikologi Perkembangan: Suatu Pendekatan Sepanjang Rentang Kehidupan. Jakarta: Erlangga. Ibyari, Fathy. (TT). Udaba'una wa al-Hubb. Cairo: Dar el-Ma'arif. Kurniawan, Hari dkk. (20150. Aksesibilitas Peradilan Bagi 
Penyandang Disabilitas. Yogyakarta: PUSHAM UII.

Lubis, Ridwan. (2015). Sosiologi Agama: Memahami Perkembangan Agama Dalam Interaksi Sosial. Jakarta: PrenadaMedia.

Madjid, Nurcholish. (2000). Masyarakat Religius: Membumikan Nilai-Nilai Islam dalam Kehidupan Masyarakat. Jakarta: Penerbit Paramadina.

Mahmud, Musthafa. (1999). Fi al-Hubb wa al-Hayah. Cairo: Dar al-Ma'arif.

Purwanta, Setia Adi.(2012) Vulnerable Groups: Kajian dan Mekanisme Perlindungannya. Yogyakarta: PUSHAM UII bekerjasama dengan Norwegian Center for Human Rights.

Qardhawi, Yusuf. (TT). Madkhal li Ma'rifat al-Islam . Cairo: Maktabah Wahbah.

Talu', Abu Bakar Ibrahim. (1995). al-Asas al-Nadzariyyah li al-Suluk al-Akhlaq. Bengazi: Jami’ah Qan Yunus. 
Halaman ini bukan sengaja untuk dikosongkan 